Article

\title{
Evaluation of Effects of Municipal Sludge Leachates on Water Quality
}

\author{
Ioannis Giannakis ${ }^{1}$, Christina Emmanouil ${ }^{2, * \mathbb{C}}$ and Athanasios Kungolos ${ }^{1}$ \\ 1 School of Civil Engineering, Aristotle University of Thessaloniki, 54124 Thessaloniki, Greece; \\ iogianna@civil.auth.gr (I.G.); kungolos@civil.auth.gr (A.K.) \\ 2 School of Spatial Planning and Development, Aristotle University of Thessaloniki, \\ 54124 Thessaloniki, Greece \\ * Correspondence: chemmanouil@plandevel.auth.gr
}

Received: 3 June 2020; Accepted: 16 July 2020; Published: 18 July 2020

\begin{abstract}
Biosolids made from municipal sludge are an attractive solution instead of chemical fertilization. Nevertheless, their effects on the ecosystem should always be considered. In the present study, anaerobically digested sludge was subjected to two leaching methods (EN 12457-2 and NEN 7341) and the main physicochemical parameters were measured in the leachates. The aquatic organisms Daphnia magna and Vibrio fischeri were exposed to the leachates in order to test for adverse effects. Mixtures of biosolid/solid, simulating the high dose of $80 \mathrm{tn} / \mathrm{ha}$, were also created, and the same parameters were measured for EN 12457-2 leachates. The results show a strong seasonal variation for the results for the municipal sludge, even though the sludge did not originate from a touristic area. The biosolid/solid mixtures did not produce toxic responses to the organism tested. Nevertheless, the parameters nitrites and nitrates in the leachates were increased in relation to control and they continued to increase even at Day 40 post-application. This increase was soil-type-dependent. The biosolids in question could be used for field fertilization, however measures should be taken against underground water nitrate pollution.
\end{abstract}

Keywords: activated sludge; biosolids; ecotoxicity; risk assessment; wastewater treatment

\section{Introduction}

Since the beginning of the last century, the management and disposal of solid and liquid municipal waste has become an important issue. Over time, this problem has been exacerbated as a result of increasing urbanization and industrialization [1]. Therefore, large amounts of municipal sludge are produced in wastewater treatment plants (WWTP), where various physicochemical and biological processes take place in order to efficiently treat wastewater [2]. This process produces an increased amount of sludge that has regularly been disposed in sanitary landfills. Data for EU-27 show that large quantities have been produced in 2006, reaching, in total, 9,866,728 th of dried solids (DS), while the average sludge production was $20 \mathrm{~kg} /$ per capita for the same year. Greece presented a modest value of $11 \mathrm{~kg} /$ per capita, however there was a clear increase when compared with values of 1999 [3]. According to the requisites of [4], the number and the capacity of WWTP is bound to be increasing in Greece.

Furthermore, new legislative and scientific directives propose the reuse of the sludge in order to assist energy and nutrient recirculation in the biosphere [5]. As such, since 2006, most EU countries have ceased depositing sludge in landfills; some of them (Sweden, Luxemburg, Holland) have completely stopped this practice, while others have reduced it to $1-2 \%$ of produced sludge. However, more than $90 \%$ of sludge which is produced in Greece ends up in landfills [3]. This is clearly a non-sustainable solution, therefore the National Solid Waste Management Plan currently in place 
dictates that only $5 \%$ of biodegradable waste can be landfilled and the remaining $95 \%$ should be managed in alternative ways [6].

In this context, it has been shown that properly treated domestic sludge in the form of biosolids may improve soil characteristics, and it may also enrich both soil matter and plant biomass with valuable micronutrients, such as $\mathrm{N}$ and $\mathrm{P}[7,8]$. Large quantities of municipal sludge are used in EU as an efficient, non-chemical means of fertilization; data from 2006 show that countries such as Spain, France, UK, Ireland and Slovakia use approximately $62-70 \%$ of their annually produced sludge as a fertilizer in agriculture [3]. This use is compatible with the principals of solid waste management, where the reuse of resources and of energy is prioritized and landfilling is the last solution.

Nevertheless, one should always consider the hazard posed by the presence of pollutants within the biosolids that may be transferred to the environment via land spreading, and especially when there is a long-term application of treated sewage sludge that may lead to a potential accumulation in soil [9]. This danger has been deemed as significant; as such, the Directive 86/278/EEC [10] has posed concentration limits for the metals of toxicological concern in the sludge and in the soil that receives it. Nowadays, the multitude of classic and of emerging environmental pollutants necessitate an update of the directive: polyaromatic hydrocarbons (PAHs) [11,12], polychlorinated biphenyls (PCBs) [11,12], various pharmaceuticals [13] have been detected in municipal sludge. Therefore, the updated sludge directive may also include limits for PCBs, PAHs, flame-retardants, pharmaceuticals and personal care products [14].

Biosolids may also affect groundwater and surface water and cause water quality deterioration. This is mostly due to the leaching of ingredients initially bound in the biosolid which then, due to climatic conditions, microbial activity, physicochemical changes or other interactions, end up in runoff or drainage. These ingredients may then pollute nearby water sources or infiltrate into groundwater. For example, it has been shown that $\mathrm{Zn}$, an important trace element, is indeed released from heavily sludge-amended soil, especially at low $\mathrm{pH}$ values [15]. Sludge spreading in typical degraded soils (containing sand or fly ash) led to the vertical mobilization of $\mathrm{Ni}$ and $\mathrm{Cd}$ deeper than $0.8 \mathrm{~m}$ in soil [16]. Nitrogen from biosolids can also leach into groundwater. Groundwater is an important resource that may satisfy human consumption and plant irrigation needs [17], but it is under constant deterioration in the Mediterranean region [18-20]. The leaching of $\mathrm{NO}_{3}{ }^{-}$to groundwater is one of the most important factors limiting the long-term viability of biosolid application to lands [21]. Elevated nitrate levels cause adverse health effects for the consumers, including neoplasias [22], methemoglobinemia [23] and cardiovascular problems [24]. The $\mathrm{NO}_{3}{ }^{-}$contamination potential of soil, when amended with biosolid, is strongly affected by the biosolid type. Liquid digested and lagooned liquid undigested biosolids seem to have the greatest accumulation due to their large content of $\mathrm{NH}_{4}{ }^{+}-\mathrm{N}$, while air-dried digested biosolids have the lowest [25].

Therefore, biosolid application in agricultural land can be beneficial and profitable when it is properly treated and used. Nevertheless, the risks should always be considered, and it is imperative that biosolids are fully characterized and processed in order not to cause harm instead of benefit when released to the environment. An effective way of assessing the environmental consequences of biosolids, when used for land application, is the use of ecotoxicity tests. Ecotoxicity tests are routinely performed in combination with chemical analyses [26], since the former can highlight the potential harmful effects on organisms.

The objectives of the present study were to characterize a number of treated biosolids produced from a WWTP in Attica (Greece) regarding their ecotoxicological potential throughout the year as well as monitoring the characteristics of mixtures of soil/treated biosolids, using practical and low-cost methods to assess their environmental impact. Therefore, samples of dehydrated and anaerobically digested sludge were subjected to two methods of leaching (EN 12457-2 and NEN 7341) and main physicochemical parameters were measured in the leachates. The aquatic organisms Daphnia magna and Vibrio fischeri were exposed to the leachates in order to simulate the environmental impact of these leachates, if they reach superficial water bodies. Additionally, mixtures of soil/biosolids were 
made and placed under controlled conditions in containers for different time intervals. Those mixtures were subjected to the EN 12457-2 one-stage batch-leaching test at a liquid to solid ratio of $10 \mathrm{~L} / \mathrm{kg}$, main physicochemical parameters were measured in the leachates and the same organisms were exposed to them. The results may act as a valuable enrichment in sludge toxicity databases and may aid the characterization of sludges regarding whether they can be used for agricultural purposes.

\section{Materials and Methods}

\subsection{Sampling and Creation of Mixtures}

Four samples of dehydrated and anaerobically digested sludge were obtained from a WWTP in Attica, which receives municipal sewage and septic sewage in four different periods: spring on 18/5/2018 (SP, rain event $0.4 \mathrm{~mm}, 22-28{ }^{\circ} \mathrm{C}$ ), summer on 7/9/2018 (SU, no rain event, $24-30{ }^{\circ} \mathrm{C}$ ), autumn on 23/10/2019 (AU, no rain event, $16-22^{\circ} \mathrm{C}$ ) and winter on 29/11/2019 (WI, no rain event, $19-22^{\circ} \mathrm{C}$ ). The sample dates were chosen according to the WWTP convenience and when no extreme weather conditions prevailed. This research was part of a preliminary analysis of the WWTP in order to test for overt toxicity of the treated sludge. In this WWTP, septic sewage is received and primarily treated in a separate system. Municipal wastewater is prescreened in 25 and $8 \mathrm{~mm}$ screens and its waste is collected and landfilled. This is followed by grit removal in a $385 \mathrm{~m}^{3}$ tank; primary sedimentation follows, and the influent is then treated in an activated sludge system of a total volume of $21,000 \mathrm{~m}^{3}$ divided into five subsections, aerated by 15 slow vertical surface aerators. Secondary (final) sedimentation is performed in two sedimentation tanks, $4570 \mathrm{~m}^{3}$ volume each. The effluent is disinfected with sodium hypochlorite and further clarified with sand filters. The WWTP has a total capacity of $24,000 \mathrm{~m}^{3} / \mathrm{day}$ of septic sewage and $20,000 \mathrm{~m}^{3} /$ day of municipal wastewater corresponding to a total organic load of $30,470 \mathrm{~kg} /$ day BOD (500,000 inhabitants). In the WWTP, primary and secondary sludge is anaerobically digested in two main digesters of $7900 \mathrm{~m}^{3}$ each, at $35^{\circ} \mathrm{C}$ for approximately 28 days. The sludge is then pumped and dehydrated to $28 \%$ DS through four gravity belt thickeners and through the addition of polyelectrolytes at $4 \mathrm{~kg} / \mathrm{tn}$ DS. The whole process is performed in a closed space equipped with deodorizer machinery. The samples ( $2 \mathrm{~kg}$ each) were taken from the final conveyor belt that carries the treated sludge to truck transfer and bagged into double-walled clear plastic bags. The bags were closed with plasticized wire, put in sealed carton boxes and transported to the Laboratory of Water Resources Engineering and Management, Division of Hydraulics and Environmental Engineering, Department of Civil Engineering of the Aristotle University of Thessaloniki. There, they were stored, wrapped with dark plastic bags and maintained in a cold room until use. Moreover, a fraction of the SP sample was mixed with two types of soils (clay or sandy) at a soil to wet sludge ratio of $50 \mathrm{w} / \mathrm{w}$ (corresponding to $80 \mathrm{tn} / \mathrm{ha}$ ) and placed in plastic containers for different time intervals (1, 15, 30 and 45 days). Finally, the containers were placed in a chamber at $20-25^{\circ} \mathrm{C}$, with adequate luminescence $(12 \mathrm{~h})$ and were impregnated with water at regular intervals to simulate field conditions.

\subsection{Leaching Tests and Parameters Tested}

The sludge samples were subjected to two methods of leaching: the static one-step method EN 12457-2 [27] and the availability test NEN 7341 [28]. All the physicochemical and ecotoxicological parameters tested (toxicity to water organisms Daphnia magna and Vibrio fischeri) were measured in the leachates. For the EN 12457-2 method, sludge moisture was calculated for all samples, in order to achieve a liquid to solid ratio of $10 \mathrm{~L} / \mathrm{kg}$ dry matter. The sludge samples were mixed with an appropriate amount of distilled water $(\mathrm{L} / \mathrm{S}=10)$ in $1 \mathrm{~L}$ polypropylene flasks. The flasks were then rotated for $24 \pm 0.5 \mathrm{~h}$ at a speed of $10 \mathrm{rpm}$ (Rotax 6.8 rotary shaker, VELP Scientifica, Usmate Velate, Italy). Subsequently, sludge mixtures were centrifuged at $4000 \mathrm{rpm}$ for $10 \mathrm{~min}$ (Rotofix $32 \mathrm{~A}$, Hettich, Tuttlingen, Germany) and filtered through $0.45 \mu \mathrm{m}$ pore filter. For the NEN 7341 leaching method, the sample was oven-dried for $24 \mathrm{~h}$, crushed and diluted with deionized water $(\mathrm{L} / \mathrm{S}=50)$ in $1 \mathrm{~L}$ polypropylene bottles. $\mathrm{HNO}_{3}(0.2 \mathrm{~N})$ was added under constant stirring ( $\left.3 \mathrm{~h}\right)$ to $\mathrm{pH} 7 \pm 0.5$. 
The mixture was then centrifugated and filtered as before, the leachate was stored and the remaining solid was carefully collected and resubmitted to dilution with deionized water (L/S = 50). $\mathrm{HNO}_{3}(1 \mathrm{~N})$ was added under constant stirring $(3 \mathrm{~h})$ to $\mathrm{pH} 4 \pm 0.5$. The second leachate was also centrifugated and filtered, and finally both leachates were mixed and stored (final L/S = 100).

The mixture samples (sludge/soil) were subjected to the EN 12457-2 one-stage batch-leaching test at a liquid to solid ratio of $10 \mathrm{~L} / \mathrm{kg}$. The main physicochemical and biochemical parameters $\mathrm{pH}$, electric conductivity, nitrates, nitrites, TOC and toxicity to the aforementioned organisms were measured in the leachates.

pH and EC were measured with a pH-meter BASIC 20+ (Crison, Barcelona, Spain) and an electrical conductivity meter WTW inoLab Cond 720 (Xylem Inc., New York, USA) respectively. For the measurement of nitrates, the LCK 339 method of the company HACH LANGE was followed [29], using known dilutions of a standard solution of nitrates (detection limits: 1-60 mg/L). Nitrites were measured according to [30] at $542 \mathrm{~nm}$ with the UV-1800 UV-Vis SHIMADZU spectrometer (SHIMADZU CORPORATION, Kyoto, Japan) using known dilutions of a standard solution of nitrites (detection limits: $0.005-0.5 \mathrm{mg} / \mathrm{L}$ ). TOC was measured according to the catalytic oxidation method [31] with combustion at $680{ }^{\circ} \mathrm{C}$ on a TOC-5000A organic carbon analyzer (SHIMADZU CORPORATION, Kyoto, Japan) using known dilutions of a standard solution of glucose $(1,5,10$ and $100 \mathrm{mg} / \mathrm{L})$ for a four-point calibration curve. The precision and accuracy of the methods is periodically checked in the laboratory using known value samples in triplicates. The organisms Daphnia magna and Vibrio fischeri that were used for the ecotoxicity tests were exposed to the leachates according to ISO Guidelines [32] and the protocol of [33], respectively.

For the Daphnia magna immobilization test, the measurement of the toxicity was based on the immobilization of the organisms after exposure to the leachates for a period of $24 \mathrm{~h}$. When it was possible, the parameter EC50 (based on the immobilization of the individuals) was calculated, through Probit Analysis (Microsoft Office 2013, Microsoft, Redmond, WA, USA) utilizing dilutions 0\%, 6.25\%, $12.5 \%, 25 \%, 50 \%, 100 \%$ of the initial leachate. Whenever the undiluted leachate could not cause at least $50 \%$ immobilization of the neonates, the parameter \% immobilization was calculated instead. For the Vibrio fischeri inhibition test, the inhibition of the bioluminescence in relation to control sample (without leachate addition) was calculated through the MicrotoxOmni 4.1 software (SDI, Newark, USA), after 5, 15 and $30 \mathrm{~min}$ of exposure. For this test, the measurement protocols used are the $81.9 \%$ Screening Test, and when it was possible, the parameter IC50 was calculated through $81.9 \%$ Basic Test. The highest sample concentration tested was $82 \%$ due to the necessary salinity adjustment.

For both D. magna and $V$. fischeri, the parameter Toxic Unit (TU) was calculated according to the formula of [34] for all available leachates. When the parameters EC50 and IC50 could be calculated, they were transformed into toxic units (TUs) according to Equation (1). Otherwise, if the effect in the undiluted leachate was below $50 \%$, the TUs were calculated proportionally (e.g., $20 \%$ effect is equivalent to $0.4 \mathrm{TU}$, and $50 \%$ effect is equivalent to $1 \mathrm{TU})$.

$$
\mathrm{TU}=\left(\frac{1}{\mathrm{EC} 50}\right) \times 100
$$

\subsection{Statistical Analyses}

The differences between seasons for each ecotoxicological parameter (D. magna immobilization, 5-, 15- and 30-min V. fischeri inhibition test) were assessed through repeated-measure ANOVA. Whenever significant differences were found $(p<0.05)$, ANOVA was followed by post-hoc HSD tests. Time differences between the biosolid/soil mixtures were assessed though two-way repeated measures ANOVA, for all the parameters with more than three repeats (TOC, nitrates, nitrites, D. magna immobilization, 5-, 15- and 30-min $V$. fischeri inhibition test). When an interaction between time duration and soil type was noted, the database was split and post-hoc HSD tests were performed in order to test for significant differences between timepoints. When no interaction was noted, only the effect of time duration was tested through post-hoc HSD tests on the database. All statistical analyses were performed using SPSS25 (IBM, Armonk, NY, USA). 


\section{Results}

\subsection{Results for the Sludge Samples}

Table 1 shows the physicochemical parameters on the leachates of the four sludges tested for both leaching tests. As can be seen on Table 1, the sludge sample of spring showed the highest moisture content and EC, while pH was the lowest, for the EN 12457-2 leaching test. On the contrary, for the same leaching test, the summer sample showed the highest $\mathrm{pH}$ and the lowest EC. Figure $1 \mathrm{a}-\mathrm{d}$ shows the EC50 values for D. magna and \% inhibition values for $V$. fischeri for each season for both leaching tests. Table 2 shows the TUs calculated according to [34] for the four sludges and for both leaching tests and organisms tested. As can be noticed in Figure 1a-d and Table 2, the spring sample showed the highest toxicity on D. magna, while the autumn sample showed the lowest toxicity for both leaching tests. Actually, there was no EC50 available for D. magna for autumn for the EN 12457-2 leaching test; this means that the undiluted leachate did not produce toxicity in at least $50 \%$ of the organisms. This is also shown in Table 2, where the corresponding TU is only 0.7. On the contrary, V. fischeri showed slightly toxic results for the spring sample, and the autumn sample showed the highest toxicity for the EN 12457-2 leaching test and the second highest for the NEN 7341 leaching test.

Table 1. Physicochemical parameters on the leachates of the four sludges tested.

\begin{tabular}{cccc}
\hline Sample & Moisture (\%) & pH & EC (mS/cm) \\
\hline SP & 77.1 & $7.35^{1 / 5.53^{2}}$ & $2.91^{1 / 4} 4.55^{2}$ \\
SU & 67.1 & $8.18^{1 / 6.23^{2}}$ & $1.49^{1 / 5} 5.08^{2}$ \\
AU & 66.7 & $7.83^{1 / 5.78^{2}}$ & $2.42^{1 / 4} 4.81^{2}$ \\
WI & 67.3 & $7.85^{1 / 5.79^{2}}$ & $1.84^{1 / 5.26^{2}}$ \\
\hline
\end{tabular}

Table 2. Toxic units (Tus) calculated according to [34] for the four sludges and for both leaching tests and organisms tested.

\begin{tabular}{cccccc}
\hline Leaching Test & Organism Tested & SP & SU & AU & WI \\
\hline \multirow{4}{*}{ EN 12457-2 } & D. magna & 4 & 2.1 & 0.7 & 1.5 \\
& V.fischeri 5 min & 0.3 & 0.8 & 1.3 & 0.8 \\
& V.fischeri 15 min & 0.2 & 0.8 & 1.5 & 0.9 \\
& V.fischeri 30 min & 0.3 & 0.8 & 1.5 & 0.9 \\
\hline \multirow{5}{*}{ NEN 7341 } & D. magna & 2 & 1.4 & 1.5 & 1.8 \\
& V.fischeri 5 min & 0.8 & 1 & 2.6 & 3.7 \\
& V.fischeri 15 min & 0.7 & 0.9 & 2.6 & 4.2 \\
& V.fischeri 30 min & 0.7 & 0.8 & 2.9 & 4.6 \\
\hline
\end{tabular}

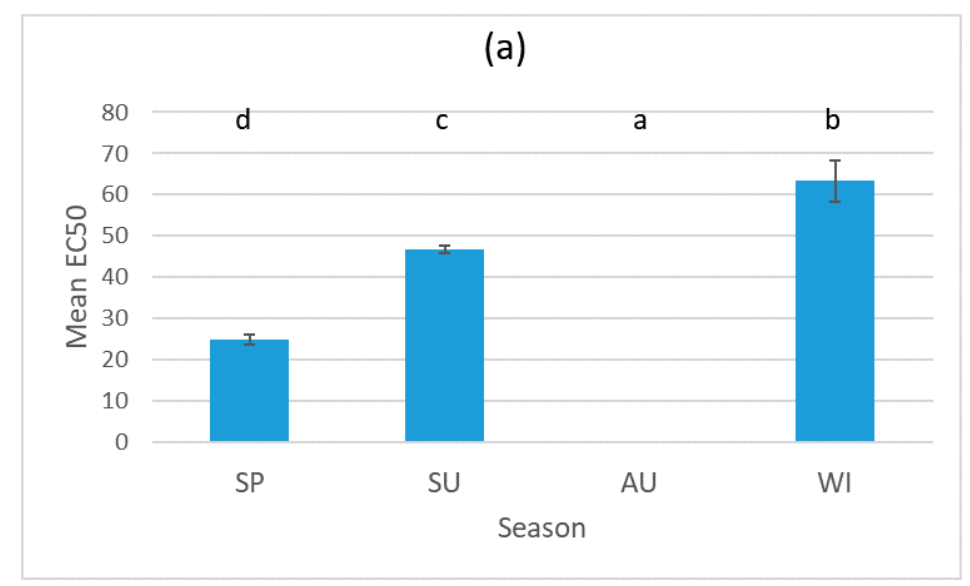

Figure 1. Cont. 

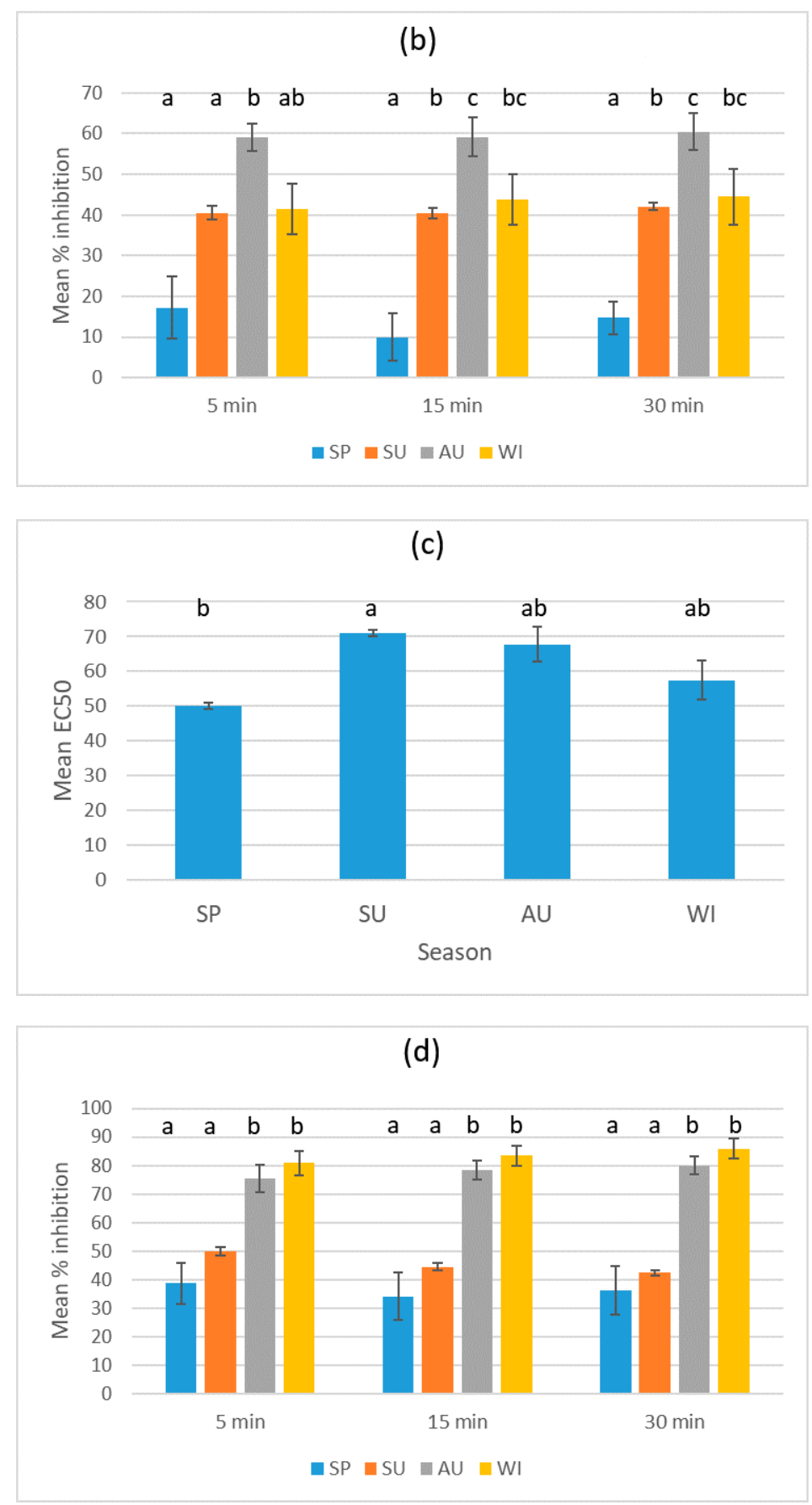

Figure 1. EC50 values for D. magna for each season $(\mathbf{a}, \mathbf{c})$ and \% inhibition values for $V$. fischeri for each season (b,d) for EN 12457-2 leaching test (a,b) and NEN 7341 leaching test (c,d). No EC50 could be calculated for AU sample in Figure 1a. Key: different letters denote statistically significant differences between the tested groups (repeated measures ANOVA followed by post-hoc HSD test).

\subsection{Results for the Biosolid-Soil Mixtures}

Different values are noted in relation to time elapsed for the measured parameters (Table 3). As shown in the line time charts (Figure $2 \mathrm{a}-\mathrm{g}$ ), the time elapsed since the biosolid application affected most of the parameters tested. For the TOC parameter, repeated measures ANOVA was conducted to explore the impact of soil type and the time elapsed since the biosolid application. The interaction effect between soil type and time duration was not statistically significant, $(\mathrm{F}=3.18, p=0.149)$. There was a statistically significant main effect of the time elapsed, $\mathrm{F}=8337, p<0.001$. Post-hoc comparisons 
showed that samples on Day 1 were not significantly different from Day 0, but, except for Day 45 , but they were different from samples on Day 15 or on Day 30. For nitrates, the interaction effect between soil type and time elapsed was highly significant, $(\mathrm{F}=64.059, p=0.001)$. There was also a statistically significant main effect of the time elapsed, $(\mathrm{F}=5875, p<0.001)$ with nitrates increasing and staying high on Day 45. For nitrites, the interaction effect between soil type and time elapsed was again highly significant, $(\mathrm{F}=39,483, p<0.001)$, while the time elapsed significantly increased nitrite leaching $(\mathrm{F}=213,368, p<0.001)$. On the contrary, both control and biosolid/soil samples were not acutely toxic for the tested organisms D. magna and $V$. fischeri. There were differences between timepoints especially for $V$. fischeri and for D. magna ( $\mathrm{F}=947.43, p<0.001$ and $\mathrm{F}=14.23, p=0.02$ respectively). Furthermore, there was no apparent difference in response between clay and sandy soil for these two tests.

Table 3. Mixtures of biosolids with sandy soil and clay soil, respectively.

\begin{tabular}{|c|c|c|c|c|c|c|c|}
\hline Treatment * & $\mathrm{pH}$ & $\begin{array}{c}\text { Electric } \\
\text { Conductivity } \\
(\mu \mathrm{S} / \mathrm{cm})\end{array}$ & $\begin{array}{l}\text { TOC } \\
(\mathrm{mg} / \mathrm{L})\end{array}$ & $\begin{array}{l}\text { Nitrates } \\
(\mathrm{mg} / \mathrm{L})\end{array}$ & $\begin{array}{l}\text { Nitrites } \\
(\mathrm{mg} / \mathrm{L})\end{array}$ & $\begin{array}{c}\text { D. magna } \\
\text { Immobilization } \\
\text { (\% in Relation to Blank) }\end{array}$ & $\begin{array}{l}\text { V. fischeri Inhibition } \\
\text { (\% in Relation to Blank) }\end{array}$ \\
\hline SA-C & 7.92 & 98.3 & $6.93 \pm 0.10$ & $3.19 \pm 0.09$ & $0.44 \pm 0.01$ & $3.33 \pm 1.67$ & $10.19 \pm 0.96$ \\
\hline SA-15 & 7.94 & 152.5 & $9.72 \pm 0.28$ & $4 \pm 0.31$ & $0.59 \pm 0.01$ & $8.33 \pm 4.41$ & $-25.99 \pm 4.19$ \\
\hline SA-30 & 7.89 & 166.2 & $9.94 \pm 0.07$ & $4.96 \pm 0.16$ & $0.83 \pm 0.01$ & $8.33 \pm 4.41$ & $-7.41 \pm 2.55$ \\
\hline SA-45 & 7.93 & 169.6 & $6.21 \pm 0.07$ & $5.36 \pm 0.07$ & $0.63 \pm 0.01$ & $3.33 \pm 1.67$ & $-19.88 \pm 1.01$ \\
\hline CL-1 & 7.91 & 170.8 & $7.07 \pm 0.06$ & $4.03 \pm 0.03$ & $0.13 \pm 0.01$ & $3.33 \pm 1.67$ & $-10.91 \pm 1.94$ \\
\hline CL-15 & 7.82 & 200 & $8.36 \pm 0.53$ & $4.32 \pm 0.04$ & $2.18 \pm 0.03$ & $6.67 \pm 1.67$ & $-15.78 \pm 1.12$ \\
\hline CL-30 & 7.84 & 206 & $9.02 \pm 0.04$ & $5.5 \pm 0.17$ & $2.41 \pm 0.02$ & $3.33 \pm 1.67$ & $-7.77 \pm 0.53$ \\
\hline CL-45 & 7.9 & 230 & $7.69 \pm 0.12$ & $7.06 \pm 0.36$ & $2.44 \pm 0.01$ & $6.67 \pm 1.67$ & $-10.28 \pm 1.05$ \\
\hline
\end{tabular}

* SA and CL means sandy and clay soil, respectively, C means sample without biosolid, and the numbers 1, 15, 30 and 45 indicate how many days have passed since biosolids have been incorporated. Data show mean value \pm SEM. Data for $V$. fischeri shown are data for $5 \mathrm{~min}$.

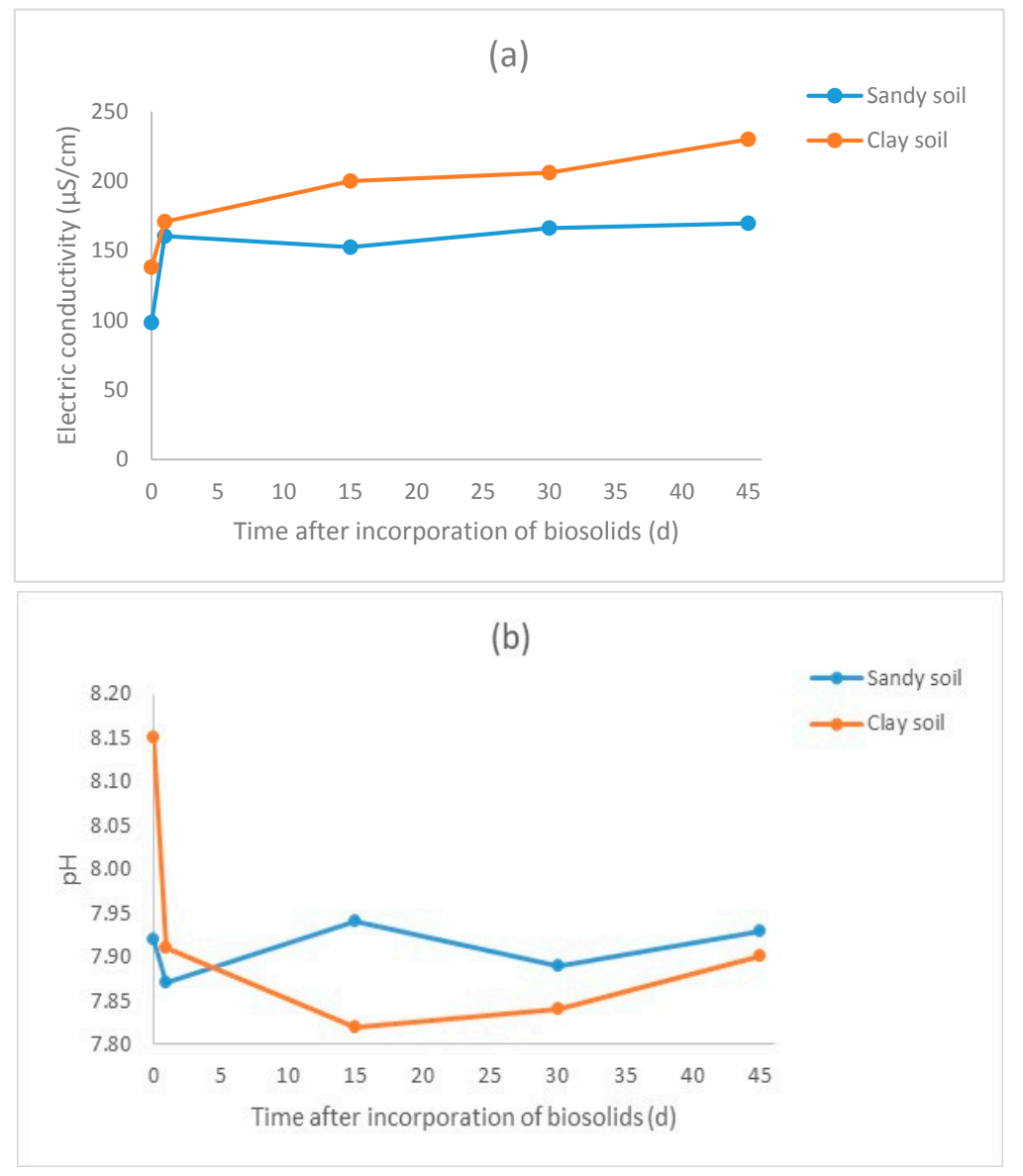

Figure 2. Cont. 


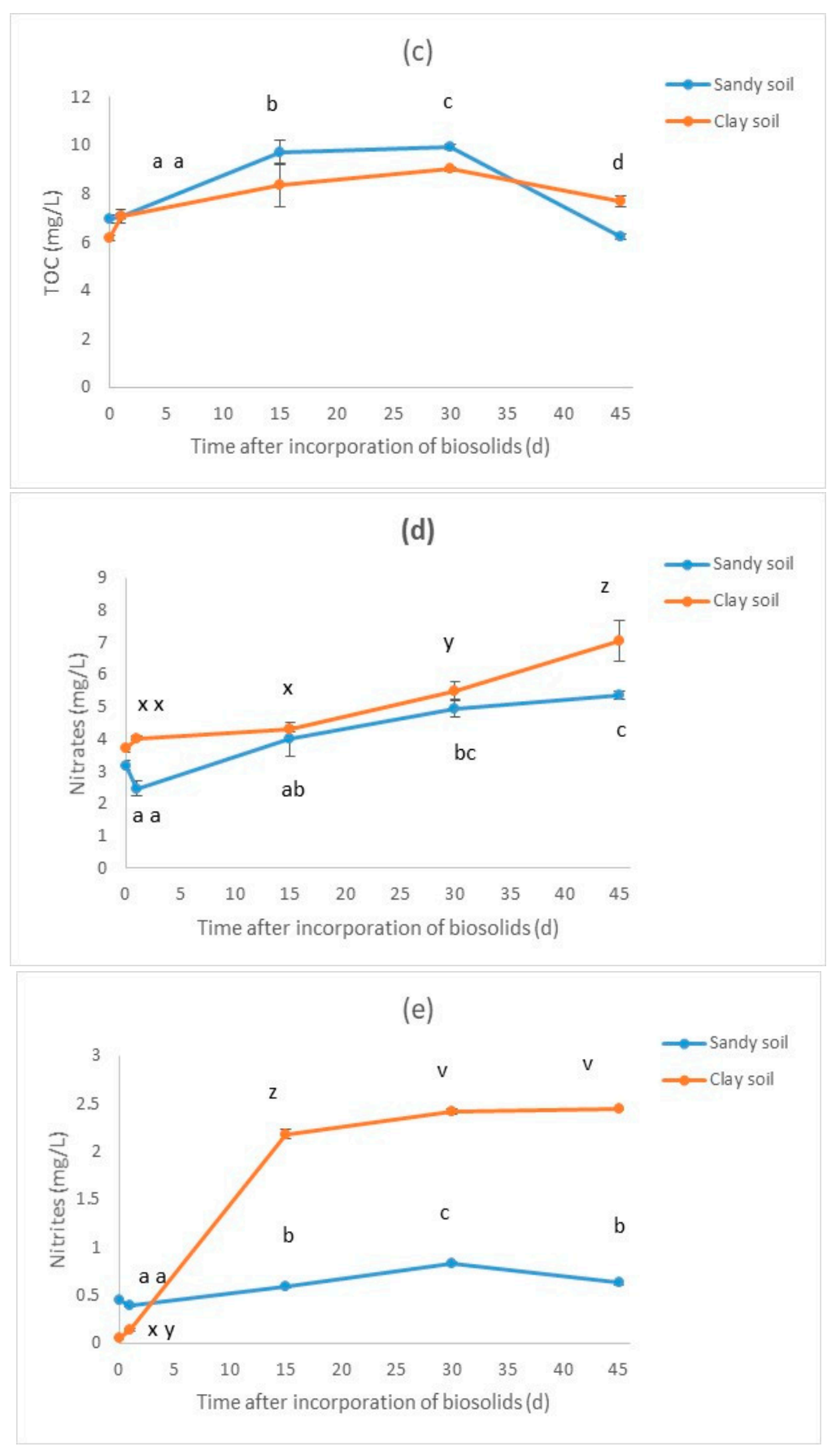

Figure 2. Cont. 

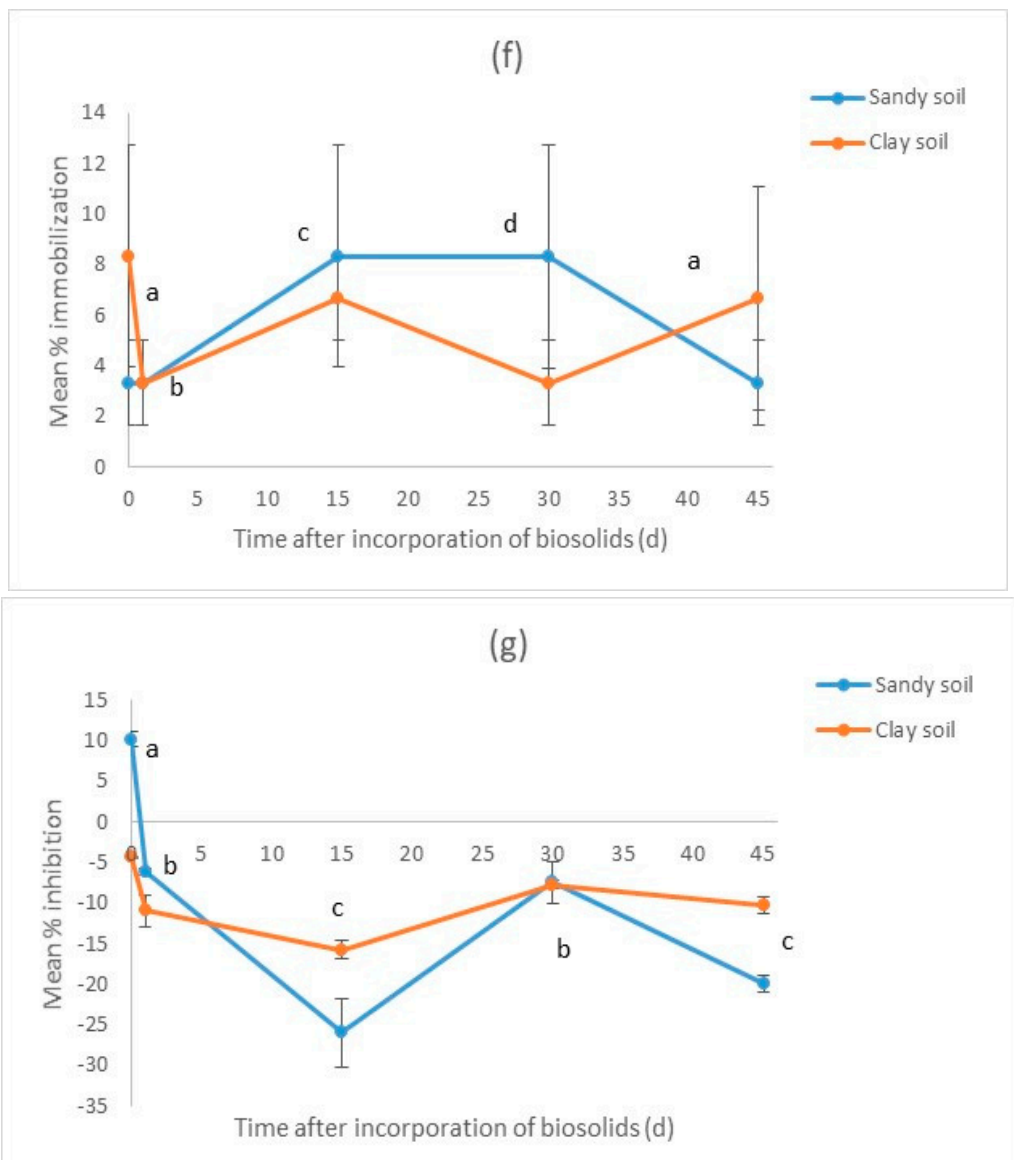

Figure 2. Time elapsed charts for electric conductivity (a), $\mathrm{pH}(\mathbf{b}), \mathrm{TOC}(\mathbf{c})$, nitrates (d), nitrites (e), \% immobilization values for D. magna (f) and \% inhibition values for $V$. fischeri (g) (the data for 15- and 30-min $V$. fischeri inhibition are not shown). A two-way repeated measures ANOVA was performed in order to test for the interaction of soil type and time duration. Different letters denote statistically significant differences between the tested groups (HSD post-hoc test).

\section{Discussion}

According to [35], the sewage sludge produced in WWTPs has increased from 6.5 million $t$ DM (dry matter) up to 9.5 million $\mathrm{t}$ DM in the last two decades. Consequently, the problems of sewage sludge management are increasing. Since the disposal of this by-product in landfills should be reduced according to directive 2008/98/EC, the land application of treated sludge in the form of biosolids as soil amendments is a sustainable solution. However, the presence of metals and other persistent pollutants may affect the applicability of land application of biosolids. The risk posed by these pollutants can be quantified through ecotoxicity tests, in combination with chemical analyses. Since the toxicants may have a synergistic effect, a potential effect cannot be predicted by the chemical analysis alone [36].

In the present study, biosolids (dehydrated and anaerobically digested sludge) were subjected to two methods of leaching tests and the organisms D. magna and $V$. fischeri were exposed to the leachates in order to evaluate their toxicity. Furthermore, biosolids were mixed with soil, placed under controlled conditions in containers for different time intervals and subjected to the EN 12457-2 one-stage batch-leaching test. The main physicochemical parameters were measured in the leachates and the same organisms were exposed to them. In this way, a simulation of an actual field spreading $(80 \mathrm{tn} / \mathrm{ha})$ was performed.

No leaching method is ideal for simulating all environmental conditions for all metals and for all kinds of organic waste; however, a few leaching methods may be sufficiently characteristic for specific ( $\mathrm{pH}$-related) environmental conditions. Therefore, two different leaching methods were chosen: 
the NEN 7341, which may simulate soil conditions of $\mathrm{pH} 3-5$, while the method EN 12457-2 may simulate conditions around $\mathrm{pH} 7-7.5$ [15].

As can be seen in Table 2, almost all leachates showed slight acute toxicity $(0.4<\mathrm{TU}<1)$ or acute toxicity $(1<\mathrm{TU}<10)$ on the two organisms tested. On the contrary, only the spring sample for EN 12457-2 leaching method and for $V$. fischeri showed no acute toxicity $(\mathrm{TU}<0.4)$. More specifically, for $D$. magna, which is characterized as one of the most effective bioassays to detect the toxicity of sludge eluates [37], almost all leachates showed acute toxicity. This was also confirmed in the study of [38], where the average toxicity against Daphnia pulex was 3.85-4.35 and 3.2-3.6 TU, respectively, for sludge press filtrates and for sludge water extracts. For $V$. fischeri, an organism that has also been reported to be highly susceptible and sensitive towards the wastewater toxicity [38], most of the leachates showed slight acute toxicity. However, autumn sample for EN 12457-2 leaching test and autumn and winter sample for NEN 7341 leaching test showed acute toxicity in Vibrio.

The toxicity levels of both organisms and leaching tests showed a large variation among the seasons. Biosolids are complex materials and, even in well managed treatment systems, it is common for the influent characteristics of a WWTP to change rapidly and unexpectedly $[39,40]$. Two of the main reasons that strongly affect the biosolid quality could be the weather conditions and the seasonal variation in the residents facilitated by the WWTP in question [41-43]. However, in our study, the samples were taken on days with little or no rain and there were no extreme temperatures for these days. Furthermore, the population of the area remains roughly the same, except for August each year, where a sharp decrease in the wastewater input is noted. The mixing of the sludge with the sludge produced from the septic tank liquid treatment may worsen the characteristics of the former and produce more toxic-treated sludge. In any case, the treatment of septic tank liquid is a common service in the WWTP in question and it has been successfully practiced for a long period of time. Higher sampling frequencies may make a significant contribution to the detailed recording of the quality of the treated sludge and can be a useful database for the evolution of the sludge quality characteristics over time.

In the mixtures of biosolids and soil that were created, no acute toxicity against the tested organisms was observed. None of the leachates were able to cause toxicity $50 \%$ or above; as such, no EC50 or IC50 could be calculated. Again, $V$. fischeri was sturdier than D. magna since most of the leachates (from the EN 12457-2 method, which was the only one performed on the biosolid/solid mixtures) caused an increase in bioluminescence and not inhibition. This may be due to the ion-rich mixture of biosolids, which usually contain large amounts of $\mathrm{K}, \mathrm{Ca}$ and $\mathrm{Mg}$ [44]. These elements, in the form of their cations, may enhance sulfur-dependent luminescence in various ways in $V$. fischeri [45]. As such, any possible toxicity was counterbalanced by this enhancement. The general lack of toxicity is in contrast with other field applications of biosolids; [46] noticed significant toxicity on D. magna ( $48 \mathrm{~h}$ test) and on plants when treated sludge was utilized, at $23 \mathrm{tn} / \mathrm{ha}$ (water elutriates). The authors of [47] noted toxicity to $V$. fischeri, dependent on the type of soil and time elapsed after incorporation, at $90 \mathrm{tn} / \mathrm{ha}$ (EN 12457-2 leachate). On the contrary, [48] did not observe significant toxicity (water elutriates, $24 \mathrm{~h}$ test, $22 \mathrm{tn} / \mathrm{ha}$ ) for D. magna after biosolid application, on Day 40. However, there was up to $20 \%$ decrease in D. magna survival, in the worst-case scenario (runoff or drainage) on Day 1. In relation to these results, the examined biosolids, even at $80 \mathrm{tn} / \mathrm{ha}$, seem to be an innocuous solution. Regarding physicochemical parameters, $\mathrm{pH}$ reduction was only observed in the clay soil. Generally, studies have shown that $\mathrm{pH}$ reduction is expected right after incorporation of treated sludge [49]. On the other hand, biosolid incorporation significantly affected the electrical conductivity and nitrates and nitrite concentrations in the leachates. This was also found in the research study of [50]. Mainly in clay, but also in sandy soil, nitrate and nitrite accumulation increased significantly as time elapsed since biosolid incorporation, as also confirmed in the studies of [21,25]. In the former study, two of the main factors controlling the rate and extent of $\mathrm{NO}_{3}{ }^{-}$were biosolid type and time duration since biosolid incorporation. Moreover, in that study, the anaerobically digested sludge was the biosolid that showed the greatest $\mathrm{NO}_{3}{ }^{-}$accumulation potential due to its large content of $\mathrm{NH}_{4}{ }^{+}-\mathrm{N}$. 
In the latter study, similar biosolid application rates accumulated $\mathrm{NO}_{3}{ }^{-}-\mathrm{N}$ up to three times as much in clay than in sandy soil.

Although, nitrite concentration in soils is usually low (below $0.1 \mathrm{mg} \mathrm{NO}_{2}{ }^{-} \mathrm{N} \mathrm{kg}^{-1}$ ), sometimes it can exceed $50 \mathrm{mg} \mathrm{NO}_{2}{ }^{-} \mathrm{N} \mathrm{kg}^{-1}$, mainly in cases of animal waste application and urea fertilizer application [51]. Excessive nitrates and nitrites in soil can lead to groundwater contamination, which has been recognized as a main reason for failing drinking water standards for decades [52]. The application of a slow-release organic fertilizer, such as this sludge-based biosolid, also caused nitrate and nitrite leaching, especially in clay soil. It would have been interesting to compare this leaching in relation to N-normalized doses of chemical fertilizers on the same type of soil. In general, the ecotoxic risk due to land application of biosolids at these rates, could be considered low; however, the contamination of underground water with nitrates/nitrites could not be excluded.

\section{Conclusions}

In the present study, anaerobically digested and dehydrated sludge was obtained from a WWTP that approximately receives $23,353 \mathrm{~m}^{3}$ /day of municipal wastewater for autumn, winter, spring and summer dates. The sludge was subjected to two leaching methods (EN 12457-2 and NEN 7341), and the main physicochemical parameters were measured in the leachates. The adverse effects of the leachates on the water organisms Daphnia magna and Vibrio fischeri were also measured. The results showed that almost all leachates showed acute toxicity for D. magna, while only some EN 12457-2 or NEN 7341 leachates showed acute toxicity on Vibrio. When the quite toxic (for D. magna) spring sample was mixed with soil (either clay or sandy soil) at the high dose of $80 \mathrm{tn} / \mathrm{ha}$, some interesting results were noted; the toxicity of these leachates towards the organisms was insignificant, and there was no effect of the type of soil on this toxicity. $\mathrm{pH}$ was reduced, as was expected after biosolid incorporation, and this was prominent in the clay soil. An increase in nitrates was noted as time elapsed, which was more prominent in the clay soil. An increase was also noted for nitrites which was very prominent in the clay soil while in the sandy soil it was modest. Therefore, some but not all physicochemical parameters were affected by the type of receiving soil. The examined sludge was assessed as harmless for water organisms in realistic scenarios, however, it was not of negligible risk on the grounds of nitrate pollution. Organic soil amendments, such as treated sludge, are an appealing fertilizing solution which transforms waste into a valuable product. Nevertheless, a detailed risk assessment encompassing multiple parameters should be performed before field application in order to protect water resources.

Author Contributions: Conceptualization, I.G. and A.K.; methodology, I.G.; software, C.E.; writing-original draft preparation, I.G.; writing - review and editing, C.E. All authors have read and agreed to the published version of the manuscript.

Funding: Giannakis' scholarship: This research is co-financed by Greece and the European Union (European Social Fund-ESF) through the Operational Programme «Human Resources Development, Education and Lifelong Learning» in the context of the project "Strengthening Human Resources Research Potential via Doctorate Research" (MIS-5000432), implemented by the State Scholarships Foundation (IK $\curlyvee$ ).

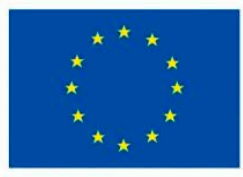

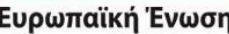
European Social Fund
Operational Programme Human Resources Development, Education and Lifelong Learning

Co-financed by Greece and the European Union
$=E \Sigma \Pi A$ E=12014-2020

Conflicts of Interest: The authors declare no conflict of interest. 


\section{References}

1. Torri, S.I.; Cabrera, M.N. The environmental impact of biosolids' land application. In Organic Waste: Management Strategies, Environmental Impact and Emerging Regulations; Nova Science Publishers: New York, NY, USA, 2017.

2. Romanowska-Duda, Z.; Pszczólkowski, W.; Pszczólkowska, A.; Wysokiñska, Z.; Grzesik, M. Use of Sewage Sludge in the Production of Plant Biomass for Energy: Biological and Economic Conditions. Comp. Econ. Res. 2012, 15, 105-122. [CrossRef]

3. European Commission; DG Environment. Final Report Part III: Project Interim Reports In Environmental, Economic and Social Impacts of the Use of Sewage Sludge on Land; Milieu Ltd.: Brussels, Belgium, 2010.

4. Council Directive 91/271/EEC of 21 May 1991 Concerning Urban Waste-Water Treatment; Official Journal of the European Union: Aberdeen, UK, 1991.

5. Directive 2008/98/EC of the European Parliament and of the Council of 19 November 2008 on Waste and Repealing Certain DIRECTIVES; Official Journal of the European Union: Aberdeen, UK, 2008.

6. Amendment and approval of the National Waste Management Plan E the National Strategic Plan on Waste Prevention; Official Government Gazette: Athens, Greece, 2015. (In Greek)

7. Zaman, M.; Kim, M.; Nakhla, G.; Singh, A.; Yang, F. Enhanced biological phosphorus removal using thermal alkaline hydrolyzed municipal wastewater biosolids. J. Environ. Sci. 2019, 86, 164-174. [CrossRef] [PubMed]

8. Groth, V.A.; Carvalho-Pereira, T.; da Silva, E.M.; Niemeyer, J.C. Ecotoxicological assessment of biosolids by microcosms. Chemosphere 2016, 161, 342-348. [CrossRef] [PubMed]

9. Clarke, R.; Peyton, D.; Healy, M.G.; Fenton, O.; Cummins, E. A quantitative risk assessment for metals in surface water following the application of biosolids to grassland. Sci. Total Environ. 2016, 566-567, 102-112. [CrossRef] [PubMed]

10. Council Directive 86/278/EEC of 12 June 1986 on the Protection of the Environment, and in Particular of the Soil, when Sewage Sludge Is Used in Agriculture; Official Journal of the European Union: Aberdeen, UK, 1986.

11. Joint Research Centre Institute for Environment and Sustainability Soil and Waste Unit. Organic Contaminants in Sewage Sludge for Agricultural Use; European Commission, Joint Research Centre Institute for Environment and Sustainability: Brussels, Belgium, 2001.

12. Smith, S.R. Organic contaminants in sewage sludge (biosolids) and their significance for agricultural recycling. Phil. Trans. R. Soc. A 2009, 367, 4005-4041. [CrossRef]

13. Verlicchi, P.; Zambello, E. Pharmaceuticals and personal care products in untreated and treated sewage sludge: Occurrence and environmental risk in the case of application on soil-A critical review. Sci. Total Environ. 2015, 538, 750-767. [CrossRef]

14. EC.europa.eu. 2020. Available online: http://ec.europa.eu/environment/waste/sludge/index.htm (accessed on 17 July 2020).

15. Van der Sloot, H.A.; Comans, R.N.J.; Meeussen, J.C.L.; Dijkstra, J.J. Leaching methods for soil, sludge and treated biowaste. Horiz. Desk Study 2003, 23, 16.

16. Luczkiewicz, A. Soil and groundwater contamination as a result of sewage sludge land application. Pol. J. Environ. Stud. 2006, 15, 869-876.

17. Alexakis, D.; Tsakiris, G. Drought impacts on karstic spring annual water potential. Application on Almyros (Heraklion Crete) brackish spring. Des. Water Treat. 2010, 16, 1-9. [CrossRef]

18. Alexakis, D. Assessment of water quality in the Messolonghi-Etoliko and Neochorio region (West Greece) using hydrochemical and statistical analysis methods. Environ. Monit. Assess. 2011, 182, 397-413. [CrossRef]

19. Stamatis, G.; Alexakis, D.; Gamvroula, D.; Migiros, G. Groundwater quality assessment in Oropos-Kalamos basin, Attica, Greece. Environ. Earth Sci. 2011, 64, 973-988. [CrossRef]

20. Gamvroula, D.; Alexakis, D.; Stamatis, G. Diagnosis of groundwater quality and assessment of contamination sources in the Megara basin (Attica, Greece). Arab. J. Geosci. 2013, 6, 2367-2381. [CrossRef]

21. Correa, R.S.; White, R.E.; Weatherley, A.J. Risk of nitrate leaching from two soils amended with biosolids. Water Res. 2006, 33, 453-462. [CrossRef]

22. Weyer, P.J.; Cerhan, J.R.; Kross, B.C.; Hallberg, G.R.; Kantamneni, J.; Breuer, G.; Jones, M.P.; Zheng, W.; Lynch, C.F. Municipal drinking water nitrate level and cancer risk in older women: The Iowa women's health study. Epidemiology 2001, 12, 327-338. [CrossRef] [PubMed] 
23. Gupta, S.K.; Gupta, R.C.; Seth, A.K.; Gupta, A.B.; Bassin, J.K.; Gupta, A. Methaemoglobinaemia in areas with high nitrate concentration in drinking water. Natl. Med. J. India. 2000, 13, 58-61.

24. WHO. Chemical fact sheets. In Guidelines for Drinking Water Quality, 4th ed.; World Health Organization: Geneva, Switzerland, 2017; pp. 296-461.

25. Smith, S.R.; Woods, V.; Evans, T.D. Nitrate dynamics in biosolids-treated soils. I. Influence of biosolids type and soil type. Biores. Technol. 1998, 66, 139-149. [CrossRef]

26. Papadimitriou, C.A.; Haritou, I.; Samaras, P.; Zouboulis, A.I. Evaluation of leaching and ecotoxicological properties of sewage sludge-fly ash mixtures. Environ. Res. 2008, 106, 340-348. [CrossRef]

27. CEN EN12457-2. Characterization of Waste-Leaching-Compliance Test for Leaching of Granular Waste Material and Sludge-Part 2; European Committee for Standardization: Brussels, Belgium, 2002.

28. NEN 7341. Leaching tests, Determination of the Availability of Inorganic Components for Leaching. In Leaching Characteristics of Solid Earthy and Stony Building Materials; Netherlands Standards: Delft, The Netherlands, 1995.

29. Rudde, H. Method of Determining a Concentration of Nitrate. U.S. Patent 9,052,292, 9 June 2015.

30. Patton, C.; Kryskalla, J. Colorimetric determination of nitrate plus nitrite in water by enzymatic reduction, automated discrete analyzer methods. In Techniques and Methods 5-B8; US Geological Survey: Reston, VA, USA, 2011; pp. 1-34.

31. Dinh, T.; Choi, I.; Son, Y.; Kim, J. A review on non-dispersive infrared gas sensors: Improvement of sensor detection limit and interference correction. Sens. Actuators B Chem. 2016, 231, 529-538. [CrossRef]

32. ISO 6341. Water Quality-Determination of the Inhibition of the Mobility of Daphnia MAGNA STRAUSS; Cladocera, Crustacea, International Organization for Standardization: Geneva, Switzerland, 1996.

33. Microbics Corporation. Microtox Manual; AZUR Environmental: Carlsbad, CA, USA, 1992.

34. Persoone, G.; Marsalek, B.; Blinova, I.; Törökne, A.; Zarina, D.; Manusadzianas, L.; Nałęcz-Jawecki, G.; Tofan, L.; Stepanova, N.; Tothova, L.; et al. A practical and user-friendly toxicity classification system with microbiotests for natural waters and wastewaters. Environ. Toxicol. 2003, 18, 395-402. [CrossRef]

35. Collivignarelli, M.C.; Abbà, A.; Frattarola, A.; Miino, M.C.; Padovani, S.; Katsoyiannis, I.; Torretta, V. Legislation for the reuse of biosolids on agricultural land in Europe: Overview. Sustainability 2019, 11, 6015. [CrossRef]

36. Garg, S.; Kansal, D. Use of Bioassay Test as a Performance Indicator in Effluent Treatment Systems including Role in encouraging shift towards use of Green Chemicals. Int. J. Mult. Res. Dev. 2014, 1, 142-145.

37. Shoji, R.; Mohri, S.; Sakai, Y.; Yamada, M. Ecotoxicity assessment of sludge and leaching test eluates of sludge. J. Environ. Sci. Health A Environ. Sci. Eng. Toxic/Hazard. Subst. Control 2008, 43, 1042-1047. [CrossRef]

38. Wlodarczyk, E.; Próba, M.; Wolny, L. Ecotoxicity Assessment of Stabilized Sewage Sludge from Municipal Sewage Treatment Plant. Civ. Environ. Eng. Rep. 2016, 22, 157-166. [CrossRef]

39. Abbas, M.; Adil, M.; Ehtisham-ul-Haque, S.; Munir, B.; Yameen, M.; Ghaffar, A.; Shar, G.A.; Asif Tahir, M.; Iqbal, M. Vibrio fischeri bioluminescence inhibition assay for ecotoxicity assessment: A review. Sci. Total Environ. 2018, 626, 1295-1309. [CrossRef] [PubMed]

40. Davies, P.S.; Murdoch, F. The Increasing Importance of Assessing Toxicity in Determining Sludge Health and Management Policy. Meas. Control 2002, 35, 238-242. [CrossRef]

41. Mikola, A.M.K.; Vahala, R.; Rautiainen, J.A. Factors affecting the quality of the plant influent and its suitability for prefermentation and the biological nutrient removal process. J. Environ. Eng. 2011, 137, 1185-1192. [CrossRef]

42. Kasina, M.; Kowalski, P.R.; Michalik, M. Seasonal changes in chemical and mineralogical composition of sewage sludge incineration residues and their potential for metallic elements and valuable components recovery. Energy Procedia 2017, 125, 34-40. [CrossRef]

43. Zhang, B.; Yu, Q.; Yan, G.; Zhu, H.; Xu, X.Y.; Zhu, L. Seasonal bacterial community succession in four typical wastewater treatment plants: Correlations between core microbes and process performance. Sci. Rep. 2018, 8, 4566. [CrossRef] [PubMed]

44. Epstein, E. Land Application of Sewage Sludge and Biosolids; CRC Press: Boca Raton, FL, USA, 2002; pp. $15-23$.

45. Tabei, Y.; Era, M.; Ogawa, A.; Morita, H. Interactions between bicarbonate, potassium, and magnesium, and sulfur-dependent induction of luminescence in Vibrio fischeri. J. Basic Microbiol. 2012, 52, 350-359. [CrossRef] 
46. Abreu-Junior, C.H.; de Lima Brossi, M.J.; Monteiro, R.T.; Cardoso, P.H.S.; da Silva Mandu, T.; Nogueira, T.A.R.; Ganga, A.; Filzmoser, P.; de Oliveira, F.C.; Firme, L.P.; et al. Effects of sewage sludge application on unfertile tropical soils evaluated by multiple approaches: A field experiment in a commercial Eucalyptus plantation. Sci. Total Environ. 2019, 655, 1457-1467. [CrossRef]

47. Malara, A.; Oleszczuk, P. Application of a battery of biotests for the determination of leachate toxicity to bacteria and invertebrates from sewage sludge-amended soil. Environ. Sci. Pollut. Res. Int. 2013, 20, 3435-3446. [CrossRef] [PubMed]

48. Gebert, S. Assessing Ecological Impacts of Land-Applied Municipal Biosolids: Effect of Run-Off and Tile Drainage on the Aquatic Organisms Daphnia Magna, Hyalella azteca and Lemna minor. Master's Thesis, Ryerson University, Ontario, ON, Canada, 2010.

49. McIvor, K.; Cogger, C.; Brown, S. Effects of biosolids based soil products on soil physical and chemical properties in urban gardens. Compost Sci. Util. 2012, 20, 199-206. [CrossRef]

50. Arduini, I.; Cardelli, R.; Pampana, S. Biosolids affect the growth, nitrogen accumulation and nitrogen leaching of barley. Plant Soil Environ. 2018, 64, 95-101.

51. Van Cleemput, O.; Samater, A.H. Nitrite in soils: Accumulation and role in the formation of gaseous $\mathrm{N}$ compounds. Fertil. Res. 1995, 45, 81-89. [CrossRef]

52. Wendland, F.; Bergmann, S.; Eisele, M.; Gömann, H.; Herrmann, F.; Kreins, P.; Kunkel, R. Model-Based Analysis of Nitrate Concentration in the Leachate-The North Rhine-Westfalia Case Study, Germany. Water 2020, 12, 550. [CrossRef]

(C) 2020 by the authors. Licensee MDPI, Basel, Switzerland. This article is an open access article distributed under the terms and conditions of the Creative Commons Attribution (CC BY) license (http://creativecommons.org/licenses/by/4.0/). 